Boston University School of Law

Scholarly Commons at Boston University School of Law

Faculty Scholarship

7-26-2013

\title{
The Fiduciary Foundations of Federal Equal Protection
}

Gary S. Lawson

Boston Univeristy School of Law

Guy Seidman

Robert Natelson

Follow this and additional works at: https://scholarship.law.bu.edu/faculty_scholarship

Part of the Constitutional Law Commons

\section{Recommended Citation}

Gary S. Lawson, Guy Seidman \& Robert Natelson, The Fiduciary Foundations of Federal Equal Protection, in No. 13-32 Boston University School of Law, Public Law Research Paper (2013).

Available at: https://scholarship.law.bu.edu/faculty_scholarship/215

This Article is brought to you for free and open access by Scholarly Commons at Boston University School of Law. It has been accepted for inclusion in Faculty Scholarship by an authorized administrator of Scholarly Commons at Boston University School of Law. For more information, please contact lawlessa@bu.edu.

BOSTON UNIVERSITY 


\title{
THE FIDUCIARY FOUNDATIONS OF FEDERAL EQUAL PROTECTION
}

Boston University School of Law Working Paper No. 13-32

(July 26, 2013)

\author{
Gary Lawson \\ Boston University School of Law \\ Guy I. Seidman \\ Interdiciplinary Center (IDC), Herzliya \\ Robert G. Natelson \\ The Independence Institute; Montana Policy Institute
}

This paper can be downloaded without charge at:

http://www.bu.edu/law/faculty/scholarship/workingpapers/2013.html 


\title{
The Fiduciary Foundations of Federal Equal Protection
}

\author{
Gary Lawson* \\ Guy I. Seidman** \\ Robert G. Natelson****
}

\begin{abstract}
In Bolling v. Sharpe, the Supreme Court invalidated school segregation in the District of Columbia by inferring a broad "federal equal protection" principle from the Due Process Clause of the Fifth Amendment. It is often assumed that this principle is inconsistent with the Constitution's original meaning and with "originalist" interpretation.

This Article demonstrates, however, that a federal equal protection principle is not only consistent with the Constitution's original meaning, but inherent in it. The Constitution was crafted as a fiduciary document of the kind that, under contemporaneous law, imposed on agents acting for more than one beneficiary-and on officials serving the general public - a well-established duty to serve all impartially. The Constitution, like other fiduciary instruments, imposes a standard of equal treatment from which lawmakers and officials cannot depart without reasonable cause. Although the Constitution's original meaning does not precisely define the answers to all "equal protection" cases, and does not necessarily prescribe norms identical to those of existing equal protection jurisprudence, it clearly does prohibit racial discrimination of the kind at issue in Bolling.
\end{abstract}

Bolling v. Sharpe ${ }^{1}$ and McCulloch v. Maryland ${ }^{2}$ are both iconic cases in American constitutional history. Beyond that status, they might appear to have

\footnotetext{
* Philip S. Beck Professor, Boston University School of Law

** Professor, Interdisciplinary Center, Herzliya.

*** Senior Fellow in Constitutional Jurisprudence, Independence Institute, Denver, Colorado; Senior Fellow in Constitutional Jurisprudence, Montana Policy Institute, Bozeman, Montana; Professor of Law (ret.), The University of Montana.

1347 U.S. 497 (1954).

217 U.S. (4 Wheat.) 316 (1819).
} 
little in common. Bolling, decided on the same day as Brown v. Board of Education, ${ }^{3}$ found unconstitutional federal laws providing for segregated schools in the District of Columbia. ${ }^{4} \mathrm{McCulloch}$ affirmed Congress's power to create and charter a national bank $^{5}$ and denied the State of Maryland's power to tax that bank. It is not obvious, at first glance, that anything of consequence connects the two decisions.

Yet certain commonalities between Bolling and McCulloch shape our understanding of a fundamental question regarding the American Constitution's original meaning: ${ }^{6}$ Does the Constitution contain a general equality norm that constrains the federal government, as one of us has suggested? 7 The question is profound as a matter of interpretation and important as a matter of practice if one

3347 U.S. 483 (1954).

4 See Act of May 20, 1862, ch. 77, § 35, 12 Stat. 394, 403; Act of May 21, 1862, ch. 83, §§ 1-3, 12 Stat. 407, 407. Strictly speaking, the statutes did not require segregated schools but rather assumed that they would be segregated by providing separately for the education of "colored children."

5 See Act of April 10, 1816, ch. 44, 4 Stat. 266.

6 The authors disagree somewhat on the interpretive force of the term "original meaning"-a common phenomenon among originalists. See Lawrence B. Solum, Faith and Fidelity: Originalism and the Possibility of Constitutional Redemption, 91 TEX. L. REv. 147, 149 (2012) ("The words 'originalism' and 'originalist' are ambiguous and used by scholars, lawyers, judges, and the public in a variety of different ways"). All of us use the term "original meaning" to describe the meaning that a hypothetical reasonable person in 1788 would have ascribed to the Constitution. See Gary Lawson \& Guy Seidman, Originalism as a Legal Enterprise, 23 Const. ComMEnTARY 47 (2006). Two of us give "original meaning" primary place in constitutional interpretation. The other points out that lawyers and courts of the Founding Era generally interpreted legal documents, such as constitutions, according to the subjective understanding of the parties that entered into them, although in the many cases in which that understanding was not recoverable or coherent, original public meaning controlled. Robert G. Natelson, The Founders' Hermeneutic: The Real Original Understanding of Original Intent, 68 OHIO ST. L.J. 1239 (2007). These intramural disputes do not affect the analysis that we undertake in this article. As often (though by no means always) happens, in this particular instance the various understandings of "originalism" converge to a common set of conclusions.

7 See Robert G. Natelson, The Constitution and the Public Trust, 52 Buff. L. REv. 1077, 1082-83, 1173-74 (2004). 
regards the Constitution's original meaning as relevant for action. ${ }^{8}$ It implicates issues ranging from the facts of Bolling, to the permissibility of federal affirmative action programs, to the ability of the federal government to make distinctions in benefit programs on the basis of sex or sexual orientation. Doctrinally, the answer to the question has been a resounding "yes" at least since Bolling was decided in 1954, and certainly since the line of modern cases that (mis?)reads Bolling as effecting a "reverse incorporation" of the Fourteenth Amendment's equality norm that binds the states. ${ }^{9}$ But what about the answer as a matter of original meaning? Does the Constitution really contain such a norm?

We believe that a principle that can plausibly, although with some important qualification, be described as a general equality norm applicable to all institutions of the national government derives from the Constitution's original meaning. This

8 Many people believe that the Constitution's meaning is at least one factor, or perhaps the determinative factor, for guiding real-world adjudications. Larry Solum calls this the "constraint principle," Solum, supra note 6, at 154, and observes that "[a]lmost every originalist agrees that the original meaning of the Constitution should make a substantial contribution to the content of constitutional law." Id. That is a contingently accurate description of current empirical reality, but-as Solum correctly notes, see id. - there is nothing in originalism as a theory of meaning that logically entails any position about originalism as a theory of adjudication. See Gary Lawson, Originalism without Obligation, -- B.U.L. REV. - (2013). Claims about meaning are in the domain of interpretative theory, while claims about appropriate action are in the domain of moral and political theory. We suggest nothing in this article about the appropriate way, if any, to translate truths about constitutional meaning into action. Even if one believes in some form of the constraint principle, the relationship between interpretation and adjudication is much more complex than is often recognized. See infra at --.

9 See Richard A. Primus, Bolling Alone, 104 Colum. L. REv. 875, 988-89 (2004). Scholars from David Bernstein to Peter Rubin have noted that, doctrinally, Bolling makes much more sense as a straightforward substantive due process case than as a vehicle for some kind of "reverse incorporation" of the Fourteenth Amendment. See DAVID E. Bernstein, Rehabilitating Lochner 87-88 (2011); David E. Bernstein, Bolling, Equal Protection, Due Process, and Lochnerphobia, 93 GEO. L.J. 1253 (2005); Peter J. Rubin, Taking Its Proper Place in the Constitutional Canon: Bolling v. Sharpe, Korematsu, and the Equal Protection Component of Fifth Amendment Due Process, 92 VA. L. REV. 1879 (2006). This seems right, though nothing in this article turns on how best to view Bolling as a matter of doctrine. 
norm, however, stems from a different source and takes a different form than that applied in Bolling, subsequent cases, and prior scholarly commentary.

Part I of this Article lays out the interpretative problem with trying to find an equality norm in the Constitution applicable to the federal government from scrutiny of the text alone. Part I then sets forth an alternative source of such a norm: the fiduciary character of the Constitution and the rules of interpretation that flow from that character. As explained in Part I, the Constitution's grants of power to federal actors and institutions are, in essence, grants to agents with fiduciary obligations, and this fiduciary understanding was inherent in Chief Justice Marshall's opinion in McCulloch. ${ }^{10}$

One of us has written elsewhere:

The Constitution should be read through a fiduciary lens. A central purpose of the document was to adopt for America a federal government whose conduct would mimic that of the private-law fiduciary. Specifically, the purpose was to erect a government in which public officials would be bound by fiduciary duties to honor the law, exercise reasonable care, remain loyal to the public interest, exercise their power in a reasonably impartial fashion, and account for violations of these duties. ${ }^{11}$

Part I thus explains what it means to read the Constitution "through a fiduciary lens"-in other words, how the character of the Constitution as an agency instrument affects how the document should be interpreted

10 To be clear: We think that Marshall's opinion in McCulloch provides an appropriate interpretative framework because parts of it are well reasoned and identify objectively important features of the Constitution, not because it was authored by John Marshall or was printed in the United States Reports.

11 Robert G. Natelson, The Legal Origins of the Necessary and Proper Clause, in GARY LAWsON, Geoffrey P. Miller, Robert G. NATElson \& Guy I. SEidman, The Origins of the Necessary and Proper Clause [hereinafter ORIGINS] 52, 52-53 (2010). 
Finally, Part I raises the question whether fiduciary requirements govern all the Constitution's grants of power or only some of them--specifically the Necessary and Proper Clause. ${ }^{2}$ This latter question is highly relevant to Bolling, since Congress's power over the District of Columbia stems from the Enclave Clause ${ }^{13}$ rather than the Necessary and Proper Clause. In other words, if we disregard the putative basis of the Bolling decision, then the result was correct as a matter of original meaning only if the Constitution's fiduciary principle governs power grants other than the Necessary and Proper Clause.

Part II of this Article then explores the content of the fiduciary norms that underlie the Constitution, in particular the norm by which agents (in this case, officials of the federal government) must treat multiple principals or beneficiaries (citizens) impartially. After surveying fiduciary law as it existed at the founding, we show that the original meaning of the Constitution prescribes a general standard of equality from which the government may depart where it can show reasonable cause. But that is as specific a conclusion as we can reach: Eighteenth-century fiduciary law was not precise enough to yield anything less general. That is why we say that commonalities between Bolling and McCulloch "shape" our understanding of the role of equality in the original Constitution. They do not necessarily provide

\footnotetext{
12 U.S. Const. art. I, § 8, cl. 18. See generally ORIGINS, supra note 11, passim (suggesting that the word "proper" in that Clause was designed to communicate that laws authorized by the Clause must comply with fiduciary standards).

13 See id. art. I,§ 8, cl. 17.
} 
concrete answers, especially if one has an unduly specific conception of what answers to constitutional questions must look like. ${ }^{14}$

Finally, Part II explains that this presumptive requirement of equal treatment applies to all federal power grants, not just to the Necessary and Proper Clause. Accordingly, Bolling was correctly decided-and quite easily correctly decided—as a matter of original meaning.

In sum, the basic idea of "federal equal protection" has a firm grounding in original meaning, though the precise content of the relevant principle is (we expect to no one's surprise) subject to considerable uncertainty. The original meaning of "federal equal protection" thus recreates—or, temporally speaking, creates-many of the puzzles that have plagued modern equal protection doctrine under the Fourteenth Amendment.

\section{I}

\section{A. The Misconceived(?) Quest for Federal Equal Protection}

Almost no one doubts that Section One of the Fourteenth Amendment ${ }^{15}$ imposes a general equality norm of some kind on the states. There is vigorous

\footnotetext{
14 There is no a priori reason to suppose that the Constitution's original meaning always will yield crisp, clear rules. The extent to which the Constitution prescribes highly specific answers is an empirical, not a theoretical, question. Perhaps (though we are not convinced) only very specific constitutional provisions are appropriate sources of law in adjudication, see Antonin Scalia, The Rule of Law As a Law of Rules, 56 U. CHI. L. REV. 1175 (1989), but any such conclusion would have to come from a theory of adjudication rather than from a theory of meaning or interpretation.
} 
disagreement about the scope and content of that norm, and even about which portion of the Fourteenth Amendment contains it, ${ }^{16}$ but there is general agreement that the Fourteenth Amendment contains some such equality norm, and we take that proposition as given in this Article.

Bolling, however, imposed an analogous requirement of equal protection on the federal government. Justifying this popular doctrine is often thought-albeit much more often by nonoriginalists than by originalists-to pose a special challenge for advocates of originalism. ${ }^{17}$

There is neither an "equal protection" nor a "privileges or immunities" clause in the Constitution applicable to the federal government. ${ }^{18}$ Instead, there are a number of clauses that mandate equal treatment in discrete contexts. Among these

15 See U.S. Const. amend. XIV, § 1 ("No State shall make or enforce any law which shall abridge the privileges or immunities of citizens of the United States; nor shall any State deprive any person of life, liberty, or property, without due process of law; nor deny to any person within its jurisdiction the equal protection of the laws").

16 Modern doctrine sees the Equal Protection Clause ("No State shall . . . deny to any person within its jurisdiction the equal protection of the laws") as the font of a general equality principle. Some originalists are inclined to see this provision as limited to the specific context of "protection" and therefore not extending to the conferral of benefits, such as access to public educational facilities, with a more general equality norm stemming instead from the Privileges or Immunities Clause ("No State shall make or enforce any law which shall abridge the privileges or immunities of citizens of the United States"). See, e.g., Steven G. Calabresi \& Andrea Mathews, Originalism and Loving v. Virginia, 2012 B.Y.U.L. REV. 1393; John Harrison, Reconstructing the Privileges or Immunities Clause, 101 YALE L.J. 1385 (1992). We do not here engage any of those debates; our focus is on the eighteenth century, not the nineteenth century.

17 See, e.g., David A. Strauss, The Living Constitution 130 (2010); William N. Eskridge, Jr., Some Effects of Identity-Based Social Movements on Constitutional Law in the Twentieth Century, 100 MiCH. L. REV. 2062, 2365 (2002) (asserting Bolling's "incompatibility with originalism"); Jeffrey Rosen, Conservatives v. Originalism, 19 HARV. J. L. \& PUB. POL'Y 465, 471 (describing Bolling as "the Achilles heel of originalism").

${ }^{18}$ Applicable to the federal government is the Privileges AND Immunities Clause, U.S. ConsT. art. I, $\S 2$, cl. 1, which was designed to impose narrower rules. See Robert G. Natelson, The Original Meaning of the Privileges and Immunities Clause, 43 GA. L. REV. 1117 (2009). 
are requirements of national uniformity for duties, imposts, and excises ${ }^{19}$ and for naturalization and bankruptcy laws. ${ }^{20}$ The commerce and taxing powers are limited by the qualification that "[n]o Preference shall be given by any Regulation of Commerce or Revenue to the Ports of one State over those of another . . ."21 The Full Faith and Credit Clause provides that Congress can implement that clause only through "general Laws." 22 The Title of Nobility Clause, ${ }^{23}$ with its prohibition on government-sponsored castes, is another equality provision. The prohibitions on bills of attainder and ex post facto laws ${ }^{24}$ insure a level of generality in certain kinds of measures. However, these are all specific requirements of equality in specific circumstances. There is no express, overarching "equality" clause applicable to federal institutions.

May one infer from these specific clauses some broader principle of equality that informs our understanding of the rest of the instrument? This kind of maneuver from a set of clauses with a common theme to a deeper interpretative principle is a familiar part of American constitutional lore: examples include John

19 See U.S. Const. art. I, § 8, cl. 1 ("all Duties, Imposts and Excises shall be uniform throughout the United States").

20 See id. art. I, § 8, cl. 4 (granting Congress power to "establish an uniform Rule of Naturalization, and uniform Laws on the subject of Bankruptcies throughout the United States").

$21 \quad$ Id. art. $1, \S 9$, cl. 6 .

$22 \quad I d$. art. IV, § 1.

23 See id. art. I, § 9, cl. 8 ("No Title of Nobility shall be granted by the United States"). For an engaging account of this neglected clause, see JAY WEXLER, ThE ODD ClaUsES: UnDERSTANDING THE Constitution Through Ten of Its Most Curious Provisions Ch. 8 (2011).

24 See id. art. I, § 9, cl. 3 ("No Bill of Attainder or ex post facto Law shall be passed"). 
Hart Ely's attempted derivation of a principle of representation, ${ }^{25}$ Zephyr Teachout's attempted derivation of an anticorruption principle, ${ }^{26}$ Heidi Kitrosser's attempted derivation of a principle of substantive accountability, ${ }^{27}$ Gary Lawson's attempted derivation of a principle of decisional independence, ${ }^{28}$ William $\mathrm{O}$. Douglas's attempted derivation of a right to privacy, ${ }^{29}$ and Roger Taney's attempted derivation of a "treat even free Blacks badly" principle. ${ }^{30}$ Given that one of us has used (he thinks correctly) this sort of maneuver in the past, we are reluctant to condemn all instances of it out of hand.

But this interpretive device must be used with great caution. After all, the most obvious interpretative inference in the face of multiple related clauses militates against this kind of interpretation: the specification of norms in certain distinct areas but not in others ordinarily suggests that no broader principle is intended. ${ }^{31}$ The more specific the instances-and the explicit equality-based provisions in the Constitution are indeed highly specific-the less likely it seems

25 See John Hart Ely, Democracy and Distrust: A Theory of Judicial Review (1980).

26 See Zephyr Teachout, The Anti-Corruption Principle, 94 CoRnELl L. REV. 341 (2009). For a spirited critique, see Seth Barrett Tillman, Citizen's United and the Scope of Professor Teachout's Anti-Corruption Principle, 107 Nw. U. L. REV. 399 (2012).

27 See Heidi Kitrosser, Reclaiming Accountability: Transparency, Executive Power, and the U.S. Constitution (2013) (forthcoming).

28 See Gary Lawson, Controlling Precedent: Congressional Regulation of Judicial Decision-Making, 18 CONST. COMMENTARY 291 (2001).

29 See Griswold v. Connecticut, 381 U.S. 479, 482-85 (1965).

30 See Scott v. Sandford, 60 U.S. (19 How.) 393, 411-12 (1856).

31 This norm is expressed in various rules of construction, of which the best known is Expressio unius est exclusio alterius - "the expression of one is the exclusion of the other." See ANTONIN SCALIA \& BRYAN A. GARNER, READING LAW: THE INTERPRETATION OF LEGAL TEXTS 107-11 (2012). 
that there is some broader norm lurking in the background. Sometimes a cigar is just a cigar. Sometimes a set of clauses with a common theme is just a set of clauses with a common theme, whose interpretative meaning is exhausted by those clauses' content.

Of course, it is possible that seemingly-related clauses are instantiations of a wider principle and that the expression of the principle in certain areas but not others is simply for emphasis or caution. In that case, though, there must be some evidence of that wider principle beyond the bare existence of a set of clauses with a common theme. ${ }^{32}$

One might find such evidence of an equality theme in the very nature of law. Perhaps the concept of law itself encompasses at least a presumptive requirement of equal treatment. The long history of acts of attainder, private bills, and special interest legislation renders this a difficult argument to make. The Constitution renders the argument even more difficult, because of the ways in which the document uses the term "law." In some instances, as in the phrase "due process of law"33 and (perhaps) "common law,"34 the meaning seems to include expansive norms. In most instances, however, when the Constitution uses the word "law," it means only a statute. ${ }^{35}$ Other than compliance with certain procedural

\footnotetext{
32 That is, there must be evidence to rebut the normal presumption, expressed in constructional preferences such as the Expressio unius maxim, that the document does not impose the wider principle.

${ }^{33}$ U.S. Const. amends. V, XIV.

${ }^{34} I d$. amend. VII.

${ }^{35}$ E.g., id. art. I, $\S 2$, cl. $3 \& \S 7$, cl. 2.
} 
requirements for the enactment of legislation and with other portions of the Constitution itself (such as the limits on federal power) nothing more is necessary to a federal "Law."

Alternatively, one might argue, as the Court did in Bolling, that a law denying equal treatment violates the Fifth Amendment's prohibition on deprivations of "life, liberty, or property, without due process of law."36 Such an argument, however, would apply only to actions effecting deprivations of life, liberty, or property, not to all federal action. Nor is this a plausible interpretation of the Due Process Clause, though to explain that point in depth would take us far afield. Suffice to say that "substantive due process," of which this would be a specific application, may or not be a plausible interpretation of the Fourteenth Amendment's Due Process Clause-but it is not a plausible interpretation of the Fifth Amendment's Due Process Clause. ${ }^{37}$

All of the foregoing suggests that the Constitution contains no specific text or set of texts that impose a general equality principle on the federal government. This, in turn, suggests that from the standpoint of original meaning the conclusion in Bolling was incorrect.

Except that there are other often-overlooked sources of constitutional meaning that bear directly on this question.

\footnotetext{
36 Id. amend. V.

37 See Ryan C. Williams, The One and Only Substantive Due Process Clause, 120 YALE L.J. 408 (2010).
} 


\section{B. Founders and Fiduciaries: Interpreting the Marshallian Constitution}

Enter McCulloch v. Maryland. The specific issues decided in McCulloch shed little light on the question before us, but Chief Justice Marshall's opinion, read for its broader framework, provides two interpretative keys vital to understanding the nature of the Constitution and the role that equality of treatment plays within it. Chief Justice Marshall deploys neither key in quite the way that we think he should have, but his analysis does suggest the correct path.

The first key lies within one of the most famous, and probably one of the most misused, sentences in American constitutional history: "We must never forget, that it is a constitution we are expounding." ${ }^{8} 8$ Here is the context in which Marshall wrote that sentence:

Among the enumerated powers, we do not find that of establishing a bank or creating a corporation. But there is no phrase in the instrument which, like the articles of confederation, excludes incidental or implied powers; and which requires that everything granted shall be expressly and minutely described .... A constitution, to contain an accurate detail of all the subdivisions of which its great powers will admit, and of all the means by which they may be carried into execution, would partake of the prolixity of a legal code, and could scarcely be embraced by the human mind. It would probably never be understood by the public. Its nature, therefore, requires, that only its great outlines should be marked, its important objects designated, and the minor ingredients which compose those objects be deduced from the nature of the objects themselves . . . . In considering this question, then, we must never forget, that it is a constitution we are expounding. ${ }^{39}$

3817 U.S. (4 Wheat.) at 407.

39 Id. at 408-09. 
Marshall was explaining that the interpretative presumptions one should apply depend in part on the kind of document one is construing. A constitution, said Marshall, is likely to be general rather than specific, so it would be a mistake to expect it to specify powers with much precision. Therefore, the absence of explicit powers to establish banks or create corporations should not weigh heavily against the existence of such powers. According to Marshall, one should interpret a constitution with the understanding that those who adopted the instrument intended to lay down general rules, not daily housekeeping details.

To thoughtful modern readers, Marshall's observation about expected levels of generality seems obviously wrong. It is true that, as Marshall noted, a constitution detailed on many matters will be long, even if not necessarily "of the prolixity of a legal code." But there is nothing conceptually absurd or illegitimate about constitutional prolixity. The Constitution of India is more than twenty five times as long as the unamended U.S. Constitution and more than fifteen times as long as the Constitution with its twenty seven amendments. ${ }^{40}$ State constitutions are often much longer and more detailed than the federal Constitution. ${ }^{41}$

$40 \quad$ India's constitution contains $117,369 \quad$ words, see http://wiki.answers.com/Q/What_is_the_length_and_breadth_of_Indian_constitution (visited Apr. 15, 2013). The American Constitution of 1788 contains 4,543 words, see http://www.archives.gov/exhibits/charters/constitution_q_and_a.html (visited Apr. 15, 2013), and with all twenty-seven amendments reaches 7,818 words. See http://www.snopes.com/language/document/cabbage.asp (visited Apr. 15, 2013).

41 Alabama's constitution exceeds 350,000 words, see http://voices.yahoo.com/the-alabama-stateconstitution-777-amendments-strong-103158.html (visited Apr. 15, 2013), though that number is misleading because the constitution contains numerous provisions involving local government and taxation. California's constitution is eight times longer than the federal Constitution fairly and 
In Marshall's defense, it must be noted that the constitutions of his day did tend to be rather short documents. The unamended U.S. Constitution contained 4543 words, the Articles of Confederation fewer than 3600, the longest state constitution (Massachusetts) about 11,400, and the constitution and declaration of rights of Virginia, Marshall's own state, only about 3800. Moreover, it may be that excessive length and detail reduce a document's effectiveness as a constitution. Yet that supra-optimal length would not render it a "non-constitution."

What make Marshall's observation more difficult to justify, even in the contemporaneous context, are the variations in detail included in different parts of the U.S. Constitution. There are a number of subjects-such as the presidential selection procedures - on which the Constitution goes into very impressive detail. ${ }^{42}$ There are other topics, of course, on which the Constitution is either terse or silent. But that means only that one cannot generalize about the expected degree of detail in the Constitution either from theorizing about the nature of constitutions or by making sweeping a priori judgments about this particular Constitution. One simply has to look topic by topic to see what level of detail is actually provided. ${ }^{43}$

squarely. See http://pacificvs.com/2009/08/18/a-brief-history-of-the-california-constitution/ (visited Apr. 15, 2013).

${ }^{42}$ U.S. Const. art. II, section 1, cls. 2-6 (containing 475 words).

43 Thus, the real question for a case like $M c C u l l o c h$ - and any other case-is more contextual than Marshall's discussion lets on: Given the particular scheme of enumerated congressional powers in Articles I-V, does the absence of an enumerated power to incorporate a bank suggest that no such power is included in the grant of authority "[t]o make all Laws which shall be necessary and proper for carrying into Execution" other federal powers?" That is a difficult interpretative question, but one is not advanced toward an answer by speculation about the specificity of constitutions. Constitutions can be long or short, detailed or vague; and the same is true of particular provisions within a constitution. The United States Constitution is, relatively speaking, on the short side, but 
But if Marshall was wrong on his precise claim, he was profoundly right in his broader point: one must never forget that it is a constitution-and not a shopping list, a poem, an inspirational speech, a Biblical passage, or a novel-that one is expounding. How one interprets a document is in some measure a function of what kind of document one is interpreting. The guidelines that govern interpretation of written instruments must be adapted to different categories of instruments. Documents designed to convey information are written and understood differently from documents designed to persuade, intrigue, or confuse. Accordingly, they require somewhat different communicative conventions. The powerful truth at the core of Marshall's aphorism is that, in order to interpret the Constitution correctly, one must first have some conception of what kind of document one is interpreting.

The Constitution has been called many things. To recite only a few, it has been called a "superstatute," 44 a "compact," 45 a "treaty," 46 a "corporate charter,"47 an

its attention to detail varies quite significantly across topics. How specific it is on any given subject is an empirical, inquiry.

44 Henry P. Monaghan, Our Perfect Constitution, 56 N.Y.U. L. REv. 353, 390 (1981).

45 Edward A. Fallone, Charters, Compacts, and Tea Parties: The Decline and Resurrection of a Delegation View of the Constitution, 45 WAKE ForEST L. REV. 1067, 1069 (2010). It must be noted that Professor Fallone was describing the "compact" theory, not endorsing it. Indeed, he argues roundly against it.

46 Francisco Forrest Martin, Our Constitution As Federal Treaty: A New Theory of United States Constitutional Construction Based on an Originalist Understanding for Addressing a New World, 31 HASTINGS CONST. L. Q. 269, 269 (2004).

47 Geoffrey P. Miller, The Corporate Law Background of the Necessary and Proper Clause, in ORIGINS, supra note 11, at144, 147 (2010). 
"instruction manual . . . for a particular form of government," 48 "a principal symbol of ... the aspirations of the tradition," 49 and "a reflection of the tension between our understanding of our present state and our understanding of social ideals toward which progress is possible." ${ }^{50}$ Some of these descriptions are closer and more helpful than others, but none of them-including the description that two of us suggested in $2006^{51}$-is exactly on target.

The person who most aptly identified the Constitution's character was James Iredell. ${ }^{52}$ Iredell was the North Carolina jurist and state attorney general (and later U.S. Supreme Court justice) who served as the chief spokesman for the Constitution at his state's ratifying convention. In the course of arguing that the Constitution did not need to include a bill of rights (or at least a bill of rights more extensive than the one appearing in Article I, section 9), Iredell said:

Of what use, therefore, can a bill of rights be in this Constitution, where the people expressly declare how much power they do give, and consequently retain all they do not? It is a declaration of particular powers by the people to their representatives, for particular purposes. It may be considered as a great power of attorney, under which no power can be exercised but what is expressly[53] given. Did any man

48 Gary Lawson \& Guy Seidman, Originalism As a Legal Enterprise, 23 Const. Commentary 47, 52 (2006).

49 Michael J. Perry, The Authority of Text, Tradition, and Reason: A Theory of Constitutional "Interpretation," 58 S. CAL. L. REV. 551, 564 (1985).

50 Margaret Jane Radin, Reconsidering the Rule of Law, 69 B.U. L. REV. 781, 816 (1989).

51 See supra note 47.

52 See Robert G. Natelson, The Agency Law Origins of the Necessary and Proper Clause, 55 CASE WESTERn Res. L. REV. 243, 305 (2004).

53 The word "expressly" should not be interpreted to mean that Iredell did not believe that the Constitution included implied powers. At the time, "expressly" could mean "not implied," but it often 
ever hear, before, that at the end of a power of attorney it was said that the attorney should not exercise more power than was there given him? Suppose, for instance, a man had lands in the counties of Anson and Caswell, and he should give another a power of attorney to sell his lands in Anson, would the other have any authority to sell the lands in Caswell? —or could he, without absurdity, say, "Tis true you have not expressly authorized me to sell the lands in Caswell; but as you had lands there, and did not say I should not, I thought I might as well sell those lands as the other." A bill of rights, as I conceive, would not only be incongruous, but dangerous. ${ }^{54}$

Iredell was making two points relevant to our discussion. ${ }^{55}$ First, and most obviously, Iredell identified the Constitution as "a great power of attorney." This is essentially and profoundly correct. The Constitution is a grant of powers from a principal, identified in the Preamble as "We the People of the United States," 56 to various designees or agents. 57 It has precisely the form, function, and feel of an agency instrument. Powers of certain kinds-some defined more precisely than

meant "clearly." See Robert G. NAtelson, The Original Constitution: What It Actually SAid AND MEANT 206 (2d ed., 2011).

544 The Debate in the State Conventions on the Adoption of the Federal Constitution 14849 (Jonathan Elliot, ed. 2d ed., 1907) (emphasis added).

55 Neither one is the point that Iredell thought was most relevant-namely, the superfluity, and indeed dangerousness, of a bill of rights. Whether Iredell was right about that point is beyond the scope of this paper. One of us has elsewhere agreed with him that a bill of rights was mostly superfluous. See Gary Lawson, The Bill of Rights as an Exclamation Point, 33 U. RICHMond L. REV. 511 (1999). It is above our pay grade to determine whether the inclusion of a bill of rights in the Constitution has done more harm than good.

56 U.S. Const. Preamble. The phrase is located in the position the grantor (the King) traditionally held in royal charters granting powers and privileges. NATELSON, supra note 53, at 27.

57 To be clear, we are making no claims that the Constitution actually, as a matter of political and moral theory, worked an effective, normatively binding transfer of authority from "We the People" to some set of governmental actors. Others have tried to use fiduciary theory to ground constitutionalism, see, e.g., Evan Fox-Decent, Sovereignty's Promise: The State as Fiduciary (2011), but that is not our project here. We are interested in constitutional meaning, not constitutional authority. For purposes of ascertaining the meaning of the document, its pretension is more important than its reality. The Constitution's character helps determine what it means. That character and meaning do not establish the truth or justice of any of its claims. 
others-are vested in different actors, whose attributes, duties, and limitations are laid out with obvious and considerable care. To be sure, the Constitution does not fit precisely the mold of traditional private-law agency instruments: the recipients of power, such as Congress, the President, and the federal courts, are not literally private-sector executors, factors, stewards, or guardians. But advocates of the Constitution routinely described federal legislators and officials as "servants," "trustees," and "agents;" 58 and the overall operation of the Constitution, as a grant of power from the principal to manage some measure of the principal's affairs, is starkly indicative of the agency character of the document. Combined with the impressive background and contextual evidence indicating that constitutive governmental instruments were seen in agency-law terms in the eighteenth century, ${ }^{59}$ the most natural, and even obvious, reading of the Constitution treats it as an entrustment of identified powers to identified agents, precisely as Iredell described it.

An alternative account, not necessarily inconsistent with Iredell's, sees the Constitution as a corporate charter and government officials as corporate officers and directors. As long as one does not try anachronistically to import modern understandings of corporations or of the duties of corporate officers into the eighteenth century, ${ }^{60}$ we do not think that much of substance changes if one

58 See Natelson, supra note 11, at 55-57.

59 See generally Natelson, supra note 7; for a shorter account, see D. Theodore Rave, Politicians as Fiduciaries, 126 HARV. L. REV. 671, 708-13 (2013).

60 Teddy Rave may have fallen prey to this anachronistic thinking in his intriguing comparison between corporate law and the obligations of politicians. See Rave, supra note 58. More 
analyzes the Constitution as a corporate charter rather than as a power of attorney.

In fact, there is considerable evidence that the founding generation, drawing upon a rich tradition in both England and America, viewed governments as corporate bodies. ${ }^{61}$ Moreover, corporate charters, like powers of attorney, represented a delegation of enumerated authority (in this case, from the sovereign) to named actors.

Yet we think that Iredell was closer to the mark. Here again $\mathrm{McCulloch}$ proves instructive: If the Constitution had been "ordain[ed] and establish[ed]" by the States, it would have had more of a corporate character. This is because it would have represented a delegation by public authorities of some of their responsibilities. ${ }^{62}$ But because the Constitution was, as Marshall wrote, "ordain[ed] and establish[ed]"by "We the People" rather than by another governmental body, ${ }^{63}$ it seems closer to a power of attorney by which "We the People" entrust to the government certain responsibilities.

Iredell's the second point is that the Constitution's character as a document has implications for the interpretative presumptions that apply to it. Marshall, as

substantively, Mr. Rave devotes most of his attention to the supposed fiduciary obligations of state governmental officials. Perhaps one can derive such obligations from individual state constitutions, see Natelson, supra note 7, at 1134-36, but the federal Constitution does not constitute the state governments, and it is thus difficult to view the federal Constitution as a source of state-officer fiduciary duties.

61 See Mary Sarah Bilder, The Corporate Origins of Judicial Review, 116 YALE L.J. 502 (2006); Eric Enlow, The Corporate Conception of the State and the Origin of Limited Constitutional Government, 6 WASH U.J. L. \& POL’Y 1 (2001); Miller, supra note 47, at 146-49.

62 See Bilder, supra note 54, at 516-17.

63 See 17 U.S. (4 Wheat.) at 402-05. 
we have seen, made the same point in $M c C u l l o c h$, even if his application of it was based on a dubious generalization about expected levels of specificity in constitutions. If the Constitution is a kind of power of attorney, it should be read as though it were a power of attorney and not, for example, a poem or inspirational speech. Both Iredell and Marshall were syllogistically correct to reason this way: (1) Agency instruments should be construed using a standard set of interpretative conventions for that class of documents, (2) the Constitution is an agency instrument, so therefore (3) the Constitution should be construed using a standard set of interpretative conventions for that class of documents.

The next question is: What are the interpretative conventions for powers of attorney? Answering this question brings us to the second interpretative key from McCulloch.

Agency instruments empower some people (agents) to act on behalf of other people (principals) over the sphere of activity defined in the instrument. This offers the benefits of specialization. It also entails the dangers of abuse: The dangers of abuse derive from that fact that even the best agents do not always have perfect knowledge, perfect motives, or perfect skills. The worst agents . . well, the facts appear throughout the course of human history.

Accordingly, a well-drafted agency instrument identifies the range of activities over which the agents can exercise their authority, anticipates problems that may arise during their representation of the principal, and specifies limitations and constraints on those agents. To itemize such information in any given instance 
might well require something of the "prolixity of a legal code." Nonetheless, because of the relative stability of human nature, many of the same kinds of problems recur; so the law of agency has developed certain default standards, principles, and rules. In other words, the mere existence of the agency relationship triggers background presumptions about the nature and scope of grants of power and about the responsibilities and duties of agents. Because these are only default standards, principles, and rules, the parties may alter them to fit the purpose of a particular instrument.

Marshall's opinion in McCulloch is written as though it is blindingly obvious, to Marshall and everyone else around him, that the Constitution is an agency instrument that incorporated background presumptions familiar from other fiduciary contexts. (Marshall himself had said as much during the ratification debates. $)^{64}$

Recall that Marshall issued his aphorism about expounding constitutions in the context of determining whether Congress could charter a bank, even in the absence of a specifically enumerated power to do so. "But," he wrote, "there is no phrase in the instrument which, like the articles of confederation, excludes incidental or implied powers; and which requires that everything granted shall be expressly and minutely described."65 Here Marshall was referring to the doctrine of imcidental authority. This was the background principle of agency law whereby a

\footnotetext{
64 See Natelson, supra note 7, at 1038, 1086 \& 1159.

6517 U.S. (4 Wheat.) at 406.
} 
grant of authority to an agent ordinarily carried with it implied, subordinate powers that, although not specifically written in the instrument, were either necessary or customary to effectuate the express ("principal") powers.66 These implied subordinate powers were referred to as incidental.

The precise range of incidental authority varied with the context. For example, when a governing instrument was silent about whether a broker (then usually called a factor) could sell on credit, he might in some circumstances be permitted to sell on credit, but in other circumstances be limited to accepting cash. A land manager (then usually called a steward) enjoyed incidental authority to lease land in some circumstances, but not in others, when the governing instrument was silent on the subject. A factor sent to negotiate a sale of goods did not have authority to sell the principal's entire business, even at a high price, unless the agency instrument expressly granted that power. Similarly, a land steward could make short-term rentals, but could not sell the fee simple without express authorization. ${ }^{67}$ A conspicuous portion of the fiduciary jurisprudence governing agents consisted of principles and rules defining what powers could be inferred as incidental in various contexts.

Grants of power in agency instruments were read against these background conventions. A full understanding of the scope of an agency required not just reading the express (principal) powers listed in the instrument, but also considering

66 For a detailed discussion of the Founding-Era law of principals and incidents, see Natelson, supra note 11 , at $60-68$.

67 See id. at 68. 
the law of incidental powers governing that instrument. In some cases, the parties might vary the background law. For example, as Marshall noted in McCulloch, the Articles of Confederation altered the baseline rule for construing such instruments by specifying that no powers, however customary or useful, could be implied from the express ones. ${ }^{68}$ In the absence of an express exception, however, agency law provided the governing default rule.

Marshall applied such a default rule in McCulloch. Today, we remember his treatment of congressional authority primarily for his interpretation of the word "necessary" in the Necessary and Proper Clause. But before Marshall reached that stage of his analysis, he spent seven pages of United States Reports trying to prove that the power to incorporate was a power of lesser dignity (that is, subordinate to ${ }^{69}$ those expressly enumerated in the Constitution. ${ }^{70}$ If the power to incorporate was not of lesser dignity to the express powers to which it was allegedly attached, then there was no way it could be incidental, no matter how causally essential it might be to their execution. ${ }^{71}$

In his discussion, Marshall recognized the Necessary and Proper Clause for what it was: a variation of a clause, very commonly found in agency agreements,

68 See ARTiCles of CONFEDERATiOn art. II ("Each state retains . . . every power, jurisdiction, and right, which is not by this confederation expressly delegated to this United States, in Congress assembled") (emphasis added).

69 The phrase most commonly used in the eighteenth-century jurisprudence was that a principal was always "more worthy than" its incident. See Natelson, supra note 11, at 61.

70 See 17 U.S. (4 Wheat.) at 413-21.

71 See generally Gary Lawson \& David B. Kopel, Bad News for Professor Koppelman: The Incidental Unconstitutionality of the Individual Mandate, 121 YALE L.J. ONLINE 267 (2011) (discussing the principal/incident distinction in the context of the Necessary and Proper Clause). 
that communicated to the reader that the parties were not opting out of the usual rules of incidental authority. In this case, the clause affirmed that the agent (Congress) enjoyed powers not specifically identified in the governing instrument, but only if those powers were incidental to the enumerated, or principal, powers granted.

For our purposes, it does not matter whether Marshall was correct to conclude that the power to incorporate was incidental to some of Congress's enumerated powers. What does matter is that he applied standard agency principles by inquiring whether the claimed power was subordinate to the enumerated principal powers. The principal/incident distinction was a governing background rule precisely because the Constitution was an agency instrument. ${ }^{72}$

Yet the background rules of agency law prevailing during the Founding Era (like the background rules of agency law today) included far more than the doctrine of incidental powers. They also imposed fiduciary obligations and limitations on agents. If factors, executors, guardians, and trustees were presumptively subject to an established set of fiduciary standards-and if the Constitution is an agency document, to be interpreted under agency principles-does not the Constitution impose on federal legislators and officials the same set, or at least a comparable set, of standards?

72 Chief Justice John Roberts, writing nearly two centuries later, understood the same point. See National Federation of Independent Business v. Sebelius, 132 S.Ct. 2566, 2591 (2012) (applying Marshall's principal/incident distinction). For analysis of Chief Justice Roberts' use of the principles of McCulloch, see Gary Lawson, Night of the Living Dead Hand: The Individual Mandate and the Zombie Constitution, 81 FordHAM L. REV. 1699, 1704-07 (2013). 
We think the answer is not simply yes, but obviously yes. In accordance with the Whig theory prevalent at the time, ${ }^{73}$ when the Constitution granted power to agents, it did so against the background of fiduciary law. Perhaps that law does not apply in precisely the same fashion to government officials as it does to private citizens, just as fiduciary standards vary somewhat among different kinds of private fiduciaries. But the underlying principles-that agents must exercise their authority with care, honesty, and attention to the interests of those who employ them-are as much part of the Constitution as the basic principles of English grammar. Federal officials are fiduciaries.

We have explained elsewhere in some detail how the Constitution applies eighteenth-century fiduciary norms to federal executive and judicial actors. ${ }^{74}$ By the time of the founding, English public law routinely applied such norms to "executive" actors, a category that included judges. Specifically, the law imposed a requirement that executive power be exercised in accordance with standards of "impartiality, efficacy, proportionality, and regard for people's rights."75 The Constitution's grants of executive and judicial power in Articles II and III carried with them the same standards. Two of us have called this the "principle of reasonableness," but this is really just a translation of standard fiduciary norms into the public law context.

73 See Robert G. Natelson, The Framing and Adoption of the Necessary and Proper Clause, in ORIGINS, supra note 11, at 84, 107, 109.

74 See Gary Lawson \& Guy Seidman, Necessity, Propriety, and Reasonableness, in OrIGINs, supra note 11 , at $120,125-33$.

75 Id. at $120-21$. 
Although the principle of reasonableness governed executive (and judicial) actors, it did not apply directly to the British legislature—-that is, to Parliament. ${ }^{76}$ This is because Parliament, unlike executive and judicial agencies, did not act pursuant to delegated power. However, the American Congress does act pursuant to delegated power: All the authority Congress possesses is delegated by "We the People" through the Constitution. Fiduciary principles are implicit in that delegation.

We previously have demonstrated that the word "proper" in the Necessary and Proper Clause refers to fiduciary standards: the use of "proper" clarifies that laws enacted under the Clause must comply with those standards. ${ }^{77}$ That conclusion is not relevant to Bolling $v$. Sharpe, because the statute at issue in that case was not adopted under the Necessary and Proper Clause. But the conclusion that fiduciary standards temper all federal powers matters a great deal Bolling $v$. Sharpe. To see why, we first explain some aspects of the fiduciary law that infuses the Constitution.

It is a bit misleading to speak of the "fiduciary law" of the Founding Era as though it was a unified doctrine. "Eighteenth-century fiduciary law was somewhat

76 See id. at 134.

77 See generally ORIGINS, supra note 11. 
fragmented, encompassing a wide spectrum of actors-administrators of estates, attorneys (both public and private), bailiffs, executors, factors, guardians, servants, stewards, and trustees."78 Nonetheless, one could generalize across these different contexts to deduce a common core of obligations imposed on all fiduciaries: the duty to stay within the limits of granted authority, the duty to act with loyalty and in good faith towards the principal, the duty of care, the duty to exercise personal discretion rather than delegate authority to another agent, the duty to account to the principal, and the duty to act impartially toward multiple principals. ${ }^{79}$ Any of these duties could be altered, added to, or subtracted from by the terms of a specific instrument, but they were the default norms governing agency relationships.

For our purposes, the most important of these baseline duties was the fiduciary duty of impartiality. This was the requirement that one acting as a fiduciary treat multiple beneficiaries in an impartial manner. For example, an executor or trustee called upon to make distributions to a class of beneficiaries generally could not discriminate unfairly among the beneficiaries. In an agency context, the duty meant that an agent had to treat his principals in an impartial manner.

There were many occasions in which a private agent might serve more than one principal: for example, a factor might represent a consortium of merchants, or a broker dealing with stock might owe duties both to the purchaser and to a secured

78 Natelson, supra note 1, at 56-57.

79 See id. at 57-59. 
lender. This is precisely the kind of multiple-principal agency arrangement created by the United States Constitution. Two of us have elsewhere argued that, for interpretative purposes, the principal who "ordain[ed] and establish[ed]" the Constitution must be viewed as a single hypothetical person. 80 But that is because of the nature of interpretation of jointly-authored documents. For purposes of trust law, there is no need for fictions about hypothetical authors or principals. In that context, "We the People" is plural (as indicated by the reference in the Preamble to "ourselves"), and once the document is "ordain[ed] and establish[ed]," the principals to be served by authorized government agents are real-life, concrete people. ${ }^{81} \mathrm{In}$ other words, the Constitution created a regime in which agents were empowered to manage some portion of the affairs of multiple principals. This imposed on those agents the fiduciary duty of impartiality.

How does this duty of impartiality require the agents to treat the principals they serve? Must they treat all of them equally?

Eighteenth-century private law does not provide an answer as crisp as one might like, but it does contain some illuminating suggestions. For our purposes, the most illustrative cases form a line of English decisions extending from the seventeenth to the beginning of the nineteenth centuries. These cases involve exercises of powers of appointment under instructions to benefit named or described

80 See Lawson \& Seidman, supra note 73, at 61-67.

81 How do we know that the instrument is established for the benefit of the people rather than for the benefit of the agents themselves? Because the instrument tells us that its purposes are "to form a more perfect Union, to establish Justice, insure domestic Tranquility, provide for the common defense, promote the general Welfare, and secure the blessings of Liberty to ourselves and our Posterity ....” U.S. Const. Preamble. 
persons, where those instructions left room for the power-holder to exercise discretion. Those powers are somewhat analogous to the federal spending powers ${ }^{82}$ in that they involve authority to expend entrusted resources. This is a rather important context when considering the actions of governments.

By the seventeenth century, it was well established that "[e]quity will in many Cases control the unequal Acts of Trustees, Guardians, \&c, though by the Deed or Will they are vested with a discretionary or arbitrary Power." ${ }^{3}$ For example, in Gibson v. Kinven, a man left property by will to his wife "upon trust and confidence that she would not dispose thereof but for the benefit of her children." ${ }^{4}$ The wife left impressive gifts to two of the surviving children but left only five shillings to the third child. That child sued to set aside the distribution although nothing in the governing will specifically constrained the wife's discretion. The defendant children explained the disparity by observing that, "the plaintiff had by some means disobliged her mother in her lifetime: and though they had endeavored to reconcile them, and to persuade the mother to leave the plaintiff her daughter a better legacy, yet they could not prevail with her to do it." 85 The case report tells us

82 We believe that the federal spending power comes from certain specific grants, such as the power to "Error! Main Document Only.support Armies" and "maintain a Navy" (U.S. ConsT. art. I, § 8, cls. 12 \& 13), and, as to grants that do not include such explicit authorization, from the Necessary and Proper Clause rather than (as modern doctrine has it) from the Taxation Clause. See GARY LAWson \& GuY SEIDMAN, The CONSTITUTion of EMPIRE: TERRITORIAL EXPANSION AND AMERICAN LEGAL HISTORY 26-32 (2004). For present purposes, the source of the spending power does not matter, as long as such power exists somewhere.

83 Craker v. Parrott (1677) 2 Chan. Cas. 228, 22 Eng. Rep. 921, 922..

84 Gibson v. Kinven (1682) 1 Vern. 66, 23 Eng. Rep. 315, 315 (1682) (italics in original).

85 Id. 
that the chancellor "decreed for the plaintiff; for that the distribution in this case was so very unequal, and that without any good reason shewn to warrant it; and therefore he thought fit to rectify it in this case, and could not do it otherwise than by decreeing an equal distribution." 86

A case decided five years before, Craker $v$. Parrott, had been to the same effect; 87 and four years after Gibson, equity claimed jurisdiction to intervene in the exercise of a similar power of appointment. That case, Wall $v$. Thurbane, ${ }^{88}$ appears to have settled before decision.

Equity continued to review for potential unfairness in exercises of even openended powers of appointment. The cases to that effect, from Gibson v. Kinven forward, were exhaustively collected and analyzed in 1801 in Kemp v. Kemp, ${ }^{89}$ by a judge who openly declared that he did not want to have to intervene in such matters but felt compelled by longstanding precedent to do so. ${ }^{90}$

Equity similarly imposed a duty of impartiality outside the context of powers of appointment. Thus, when a factor represented multiple principals and the buyer failed to pay, the principals had to share the loss equally:

One and the same factor may act for several Merchants, who must run the joynt risque of his actions ... ; as if five Merchants shall remit to one Factor five distinct Bales of Goods, and the Factor makes

\footnotetext{
86 Id. at 315-16.

87 See 22 Eng. Rep. at 922.

88 (1686) 1 Vern. 415, 23 Eng. Rep. 555, 555.

89 (1801) 5 Ves. Jr. 849, 31 Eng. Rep. 891.

$90 \quad$ See id. at 897.
} 
one joynt Sale of them to one Man, who is to pay one moiety down, and the other at six Months end; if the Vendee breaks before the second payment, each man must bear an equal share of the loss . . . ${ }^{91}$

From such cases, we might conclude that the duty of impartiality always required equal treatment of beneficiaries or principals. But this is not quite true. Instruments at issue in later cases seemed to give the power-holder broader authority than that enjoyed in the Gibson and Craker cases. ${ }^{92}$ After some balking, ${ }^{93}$ the courts began to honor this language by, in proper instances, upholding unequal distributions.

Thus, in Burrell v. Burrell, 94 a wife charged by a testamentary power of appointment to provide her children "such fortune as she should think proper or they deserve,"95 made only token provision for a son who already had a substantial income as result of past actions by the original testator. The court held that she "had executed the power [of appointment] very properly, considering the provision

913 Charles Molloy, De Jure Maritimo et Navali, or A Treatise of Affairs Maritime and of COMMERCE 466 ( $7^{\text {th }}$ ed., 1722).

92 Drafters were always free to authorize, or even mandate, unequal treatment of beneficiaries. For example, when a power of appointment authorized distribution "to one or more of the children then living, in such manner as his wife, whom he had made executrix, should think fit," Thomas $v$. Thomas, 23 Eng. Rep. 928 (1705) (emphasis added), it was permissible to make the entire distribution to one child, because while "an unreasonable and indiscreet disposition may be controlled by a Court of Equity . . . it is expressly provided, that she might give all to one." Id. Subsequent case law made clear that language of this sort was both necessary and sufficient to allow full dispositions to one member of the potential beneficiary class. See Kemp, 31 Eng. Rep. at 895.

93 E.g., Astry v. Astry (1706) Prec. Ch. 256, 24 Eng. Rep. 124 (mandating equality despite instrument seeming to grant wide discretion: "in such proportions as she should think fit"). For examples of the subsequent approach in addition to Burrell, see Maddison v. Andrew, (1747) 1 Ves. Sr. 58, 27 Eng. Rep. 889; Alexander v. Alexander (1755) 2 Ves. Sr. 641, 28 Eng. Rep. 408.

94 (1768) Amb. 660, 27 Eng. Rep. 428.

$95 \quad I d$. at 428. 
which the son was entitled to ...."96 In other words, if the instrument and underlying facts offered good reason to do so, in some circumstances even wildly unequal treatment was proper. When enforcing such instruments, as the court explained in Kemp, the law presumed merely that each beneficiary should receive something substantial, or not "illusory,"97 but not necessarily something equal to the other beneficiaries. ${ }^{98}$

This is not a surprising result: Not only had the creator of the instrument emphasized the breadth of the power-holder's discretion, but a strict focus on equality raises the age-old problem of defining the dimensions along which equality is going to be measured. Does giving every beneficiary the same amount constitute equal treatment when one of those beneficiaries already has an enormous income from prior actions of testator? It depends on what is being measured as equal or unequal. Moreover, the law was not concerned with seemingly inequitable distributions in the abstract but with seemingly inequitable distributions for which there was no good cause, no apparent reason. As the rule was expressed in 1706, where a power is given to make distributions to children, the holder of the power of appointment "must divide it amongst them equally, unless a good reason can be given for doing otherwise." ${ }^{99}$ Later cases also emphasized the importance of giving

$96 \quad I d$. at 429.

97 Astry v. Astry (1706) Prec. Ch. 256, 24 Eng. Rep. 124.

$98 \quad$ See 31 Eng. Rep. at 896-98.

99 Astry, 24 Eng. Rep. at 124 (emphasis added). 
reasons for seemingly unequal or unfair treatment, ${ }^{100}$ though by 1801 at least one judge (concededly hostile to the entire line of cases) doubted whether equality was the proper baseline, 101 maintaining instead that "it is perfectly clear . . ., if some very good reason does not appear ... for giving a very small sum to one, such a disposition cannot be allowed."102

Thus, the essence of the law was that unexplained or unjustified unfairness in the distribution of assets was a violation of an agent's fiduciary duty, even when the instrument granted the agent seemingly limitless discretion. Under certain circumstances, fairness and equality overlapped, such as when unequal treatment (however "unequal" was defined in that context) was per se unfair. Indeed, when no better result was obvious, equal treatment was the default rule. But in other circumstances, fairness required some accommodation to everyone, although not necessarily the same accommodation.

Convenience justifies fixing as a baseline a presumption of equality of distribution of burdens (as in the case of merchants who suffered losses from nonpayment) or benefits (as in the distribution of assets under a power of appointment). However, the courts permitted deviations from the baseline when good reasons supported a deviation. The result was a judicial requirement of fair or

100 See Kemp, 31 Eng. Rep. at 893 ("the point is whether, under such a power she could make such [unequal] distribution; assigning no reason for so doing. For that there is no authority.") (argument of counsel).

101 See id. at 896 (saying of Astry's emphasis on equality: "That I take not to be the rule of the Court now"). It is not clear whether the judge was taking into account the greater discretion allowed in the later instruments.

$102 I d$. 
reasonable treatment. This might or might not translate into a requirement of equal treatment, depending upon circumstances.

During the period before the founding, the same themes appeared in public sector agency law. The seminal decision was Rooke's Case, ${ }^{103}$ about which two of us have written elsewhere.104 A statute gave sewer commissioners power to make repairs to water-control utilities "as case shall require, after your wisdoms and discretions." 105 The costs were to be assessed on affected landowners as the commissioners "shall deem most convenient to be ordained."106 In Rooke's Case, the commissioners had assessed all of the costs of repair to a river bank on one landowner, despite the fact that "divers other Persons had Lands to the Quantity of 800 Acres within the same level, and subject to Drowning, if the said bank be not repaired . . ." 107 As reported by Sir Edward Coke, the court ruled that the commissioners exceeded their authority, even though the statute seemed to give them unlimited discretion to assess repair costs as they saw fit: "[N]otwithstanding the Words of the commission give Authority to the commissioners to do according to their Discretions, yet their Proceedings ought to be limited and bound with the Rule of Reason and law."108 As no reason was evident why just one landowner should

103 (1598) 5 Co. Rep. 99b, 77 Eng. Rep. 209.

104 See Lawson \& Seidman, supra note 73, at 122-23, 137-38.

10523 Hen. 8, c. V, § 3, cl. 2 (1531), 4 Stat. at Large 223, 224 (1763).

$106 \quad$ Id. cl. 3.

10777 Eng. Rep. at 209.

$108 I d$. at 210. 
bear the entire cost of repair, the assessment was invalid. Rooke's Case noted that the applicable statutes required equality, which, it observed was consistent with the equitable law of bankruptcy, ${ }^{109}$ so that "the commissioners ought to tax all who are in danger of being damaged by the not repairing equally." 110

Equality of treatment also played a significant role in Keighley's Case ${ }^{111}$ in 1609, eleven years after Rooke’s Case. In Keighley, the commissioners again sought to place the entire burden of keeping a wall in good repair on one landowner, while the court ruled that the commissioners "ought to tax all persons who hold any lands or tenements . . according to the quantity of their land . ..."112 Here a particular measure of equality—payment in accordance with amount of land—was put forward as the explicit baseline. Thus, Keighley went beyond holding that one landowner should not have borne the entire burden; it further held that all landowners should have borne their proportionate burdens.

Rooke's Case and Keighley's Case demonstrate that, as early as the sixteenth century the courts were applying fiduciary standards to public officials somewhat comparable to those imposed on private agents. ${ }^{113}$ If this public fiduciary law was part of the background against which the Constitution was "ordain[ed] and

109 Id. at 210 ("said statutes require equality, which well agrees with the rule of equity").

$110 I d$. at 209 (emphasis added).

111 (1609) 10 Co. Rep. 139a, 77 Eng. Rep. 1136.

$112 I d$.

113 English political writers and speakers also were drawing comparisons between government and trust duties as early as the sixteenth century. See Natelson, supra note 7, at 1101-23. 
establish[ed]"-and we think it more than clear that it was-then what does it tell us about the obligations of federal government officials operating under a "great power of attorney"?

It is easy to say that executive and judicial actors, who, like the English sewer commissioners, exercise delegated, implementational power, are bound to exercise their discretionary authority with care, loyalty, and impartiality. ${ }^{114}$ Does the obligation of "impartiality" require equal treatment of all beneficiaries (or, in the agency context, principals) along all possible understandings of equality? Of course not. But it does mean that executive and judicial actors have to explain why they are treating people as they do whenever the reasons for the different treatment are not obvious. Equality of treatment is a plausible baseline from which to begin. One can deviate from that baseline in certain circumstances, or even decide that a different baseline is appropriate, but one will need reasons for so doing. The President does not, for example, need to commit law enforcement resources in a manner proportional to population. But if he varies from the requirement of a rough equality, he should be able to show reasonable cause for doing so. An allocation grossly unequal in some important respect (favoring, let us say, Chicago over Houston) requires some explanation.

Is the same true of legislation? There is no obvious reason why not. Members of Congress are fiduciary agents just as presidents and federal judges are. They, too, exercise delegated power, and only delegated power, derived from the principal who

114 And so we have said at some length elsewhere. See Lawson \& Seidman, supra note 74. 
empowered them: "We the People." Accordingly, they owe fiduciary duties to the principals whose affairs they manage. Once again, equality should serve as a baseline, and deviations from the baseline should be supported by reasonable cause.

Thus, it is partly misleading to say that the fiduciary obligations of federal officials under the Constitution include a duty to provide "equal protection." That formulation suggests concrete conceptions of equality that must be strictly followed. Instead, one perhaps should speak of "fair protection," or perhaps even more accurately "reasoned protection." The fundamental obligation of the fiduciary is not always to treat beneficiaries or principals in equal circumstances equally, but not to treat them unequally without good reason. There are contexts in which unequal treatment is prima facie, or even per se, unreasonable, and in those circumstances the requirement of "reasoned protection" folds into one of "equal protection." But those will be special cases of the broader principle.

In what sort of context might fiduciary obligations require equal treatment? The obvious answer is, "Contexts in which the stated (or unstated) grounds for distinction proposed by the agent are not supported by any reasonable cause." For example, when the purpose of a will that includes a power of appointment is to effectuate the presumed intent of the testator, there is reasonable cause for differential distributions under the will's power of appointment when the testator himself already provided one of the children with a large income. There is no reasonable cause, however, for differential distributions because one of the children has "disobliged" the person making the appointment, where the purpose of the 
distribution was to effectuate the presumed intent of the deceased father. Some reasons simply do not make sense in the context of particular agency relationships. ${ }^{115}$ The fact that one cannot give precise or determinate content to this norm does not mean that the norm has no force or cannot be applied. It may well result in some very difficult cases, but that is why judges and lawyers are paid.

There are some easy cases as well. Does it make any sense for government officials to discriminate on the basis of race? In Plessy v. Ferguson, ${ }^{116}$ a majority of the Supreme Court thought so—finding segregation, allegedly without disparate treatment, to be "reasonable." In reaching that conclusion, however, the majority of the Justices not only disingenuously denied that segregation was designed as a badge of black inferiority, but they also were notably deficient in identifying allegedly reasonable bases for separation of the races. The reasons they did offer were "the established usages, customs and traditions of the people"117 (without noting that strict segregation in the South was a fairly new, post-bellum phenomenon) and "comfort, and the preservation of the public peace, and good order" (thereby making the bigotry of some principals a justification for punishing other principals).

115 Context matters. To use a farcical example, would it be unreasonable for someone exercising a power of appointment to deny a beneficiary a share because that beneficiary was a vegan? That might depend on the presumed intent of the person creating the instrument. For example, suppose the person creating the instrument had made his fortune from operating a slaughterhouse?

116160 U.S. 537 (1895).

117 Id. at 550 . 
On the other hand, one might think of circumstances where disparate racial treatment made sense. It would not, for example, be irrational to deny an FBI agent a potentially career-advancing undercover assignment because the agent is black and the assignment calls for infiltrating the Aryan Nation. Moreover, some have argued that it is reasonable for a state prison system to segregate prisoners by race when necessary to control gang violence. ${ }^{118}$ Still others have contended that racial discrimination is permissible to create a racially diverse environment in institutions of higher learning. ${ }^{119}$ But the latter instances plumb the outer boundaries of plausible arguments. In the overwhelming majority of cases, it will be next to impossible to find any good reasons for that kind of discrimination. Indulging in it would appear to be a clear violation of the fiduciary duty of government agents.

Is there a wider range of circumstances in which the federal government would have good cause to discriminate on the basis of sex rather than race? On the basis of sexual orientation? On the basis of wealth? If the presumptive requirement of fiduciary law is equal treatment of principals/beneficiaries, it is hard to see how one could avoid asking these kinds of questions. To answer them, of course, requires knowing some things that are very difficult to know: What counts as "reasonable cause" for an action? Do reasons for actions have to be tailored to individual circumstances or may they be based upon generalizations? If the latter, how accurate do those generalizations need to be? What classes of people are appropriate for generalizations? How compelling do the government's reasons for

118 See Johnson v. California, 543 U.S. 499, 523-24 (Thomas, J., dissenting).

119 See Grutter v. Bollinger, 539 U.S. 306, 328-33 (2003). 
actions have to be in different circumstances? Do those reasons need to have the same force regardless of the basis for the differential treatment and regardless of the characteristics of the people burdened and benefited by the action? Does discrimination on the basis of race require a stronger, weaker, or identical strength of reason than discrimination on the basis of sex? Do the reasons require the same force when one is considering (a) the administration of benefit programs, (b) the operation of a prison system, or (c) the management of the military? What would a jurisprudence involving judicial enforcement of this kind of fiduciary duty look like?

We have seen how differences in the wording of instruments induced the English courts to be more or less tolerant of inequities of treatment. Is the same true of different provisions in the Constitution? For example, if a constitutional provision contains one sort of "equal protection" provision (such as the requirement that bankruptcy laws be uniform), does that suggest that other kinds of equality standards are not to be added? Suppose the history behind a provision suggests that discriminatory treatment was expected? The Commerce Clause was adopted with the understanding that it would permit Congress to lay discriminatory regulations against certain goods. Should that make a difference? In Fourteenth Amendment Equal Protection Clause cases, courts give heighted protection to racial groups precisely because of that Clause's central purpose and history.

We do not intend even to begin to answer this list of questions. Instead, we want to emphasize three features of the list. First, it recreates almost perfectly the set of questions raised (if not always directly addressed) by modern equal protection 
doctrine. ${ }^{120}$ The original "federal equal protection" doctrine found in the Constitution of 1788 is likely to give rise to the same kinds of problems, conundrums, and value choices with which the law has wrestled for a century and a half when trying to understand the Fourteenth Amendment.

Second, while the questions are likely to be very similar under the federal fiduciary and Fourteenth Amendment "equal protection" doctrines, it is not at all certain that the answers will always be the same. The Constitution did not create the state governments and therefore, in most instances, does not function as a "great power of attorney" with respect to the States.121 Fourteenth Amendment equal protection doctrine springs from the text of a particular constitutional amendment rather than from the general fiduciary character of the Constitution. Accordingly, the interpretive rules that accompany the Constitution and create a presumptive requirement of equal treatment by federal officials, do not necessarily apply to questions involving the States.

Perhaps, at the end of the day, there will be substantial overlap between the fiduciary constraints on imposed on federal agents and the Fourteenth Amendment constraints imposed on state agents, but there is no a priori reason to expect them to be identical. Chief Justice Warren in Bolling wrote that "it would be unthinkable

120 Compare our list of questions to the summary of equal protection law found in a leading constitutional law casebook. See Michael Stokes Paulsen, Steven G. Calabresi, Michael W. McConnell \& SAmuel L. Bray, The Constitution of the United States 1511-12 (2010).

121 There are limited contexts, such as the provisions empowering state governments to act in connection with federal elections and the power of state legislatures, under Article V, to apply for amendments and designate convention delegates, in which "federal equal protection" standards might well apply to States in the same fashion that they applies to the federal government. We do not pursue that line of analysis here, though we invite others to do so. 
that the same Constitution would impose a lesser duty on the Federal Government"122 than it imposes on the States. To the contrary, because the "equal protection" constraints on the two levels of government stem from independent constitutional sources, it is eminently thinkable that the federal government might have a lesser, or even a greater, duty in some circumstances than do the States. ${ }^{123}$

Third, questions about the character of a jurisprudence that takes fiduciary duties seriously involve issues different from those we have discussed. Our focus has been on discerning constitutional meaning, and we have no trouble saying that the federal Constitution means that federal government officials must have plausible reasons when discriminating among classes of citizens. That is no more difficult than saying that a trustee needs to have good reasons for his or her actions when he or she treats some beneficiaries more favorably than other beneficiaries, or that an agent must have good reasons for discriminating among principals. The strength of the required reasons will vary with context, but an utterly arbitrary action by a fiduciary that discriminates among beneficiaries or principals is always a breach of duty. The Constitution imposes a similar rule on federal actors, unless one can discern specific contexts in which that general requirement does not apply. ${ }^{124}$ But determining how, or even whether, to translate that meaning into

122347 U.S. at 500.

123 Cf. Steven G. Calabresi, A Madisonian Interpretation of the Equal Protection Doctrine, 91 YALE L.J. 1403 (1982) (arguing that Madisonian political theory suggests that equal protection principles should apply more strictly to states than to the federal government).

124 One of us has previously hesitated to reach this sweeping a conclusion about a general constitutional requirement of reasonableness. See Gary Lawson, Ordinary Powers in Extraordinary 
real-world constitutional doctrine requires a completely different kind of inquiry than we have undertaken here.

The move from meaning to real-world doctrine requires a theory about a very complex relationship between what a document means and how people should behave. Many people assume that once the Constitution's meaning is discerned, it follows naturally that political actors, such as judges, should act in accordance with that known meaning. As one of us has emphasized to tedium, however, that is an assumption far less inevitable than widespread. ${ }^{125}$

Propositions about constitutional meaning are factual statements whose truth or falsity is determined by the tools of interpretative theory, while propositions about constitutional doctrine, which purport to dictate appropriate conduct, are normative claims whose truth or falsity must be determined by political and moral theory. Evidence that supports one kind of claim may or may not support other kinds of claims. Even assuming that constitutional meaning is relevant to constitutional action, it is far from obvious that adjudication either can or should directly apply what one regards as the correct theory of constitutional meaning (whatever that theory may be). Adjudication takes place in real time, with limited resources. Anyone who says that there is no price tag on justice understands neither price tags nor justice. It is virtually inevitable that any sensible, workable

Times: Common Sense in Times of Crisis, 87 B.U.L. REV. 289, 309 (2007). But one must go where the evidence leads, and that is where the evidence leads.

125 See, e.g., Gary Lawson, On Reading Recipes ... and Constitutions, 85 GEO. L.J. 1823 (1997). 
system of adjudication will adopt shortcuts, or rules of thumb, for dealing with recurring situations, which almost certainly means that some decisions that are adjudicatively "correct" will be interpretatively "wrong," simply because getting the interpretatively "correct" answer would be too costly. ${ }^{126}$ A theory of adjudication probably cannot follow in a straight line from a theory of interpretation even if the conceptual and normative gap between meaning and adjudication can be bridged.

Thus, we present here no theory about the appropriate way to translate constitutional meaning into constitutional adjudication. We conclude only that the Constitution's meaning includes fiduciary obligations on federal officials; we do not say whether courts can or should enforce those obligations in any particular fashion.

In the end, we do not believe that the Constitution prescribes precise and detailed answers to what constitutes "reasonable cause," any more than the law of trusts provides precise and detailed answers to every question of how to execute a power of appointment. We maintain only that the original Constitution poses those questions. If one wants to call those questions, and the need of governmental fiduciaries to answer them in the course of executing official duties, a species of "federal equal protection," we do not object strongly to that label. And if one wants to describe the process of discerning the character and strength of the needed reasons for action as a "moral reading"127 or "philosophical approach"128 to

\footnotetext{
126 See Gary Lawson, Originalism without Obligation, -- B.U.L. REV. - (2013) (forthcoming).

127 See James E. Fleming, Living Originalism and Living Constitutionalism as Moral Readings of the American Constitution, 92 B.U.L. REV. 1171, 1173 (2012).

128 See Sotirios A. Barber \& James E. Fleming, Constitutional Interpretation: The Basic QUESTIONS 155-70 (2007).
} 
constitutional interpretation, we do not object strongly to those labels either. We think, however, that "fiduciary approach" better describes the required inquiry. This is because our focus is on the distinctively legal content of fiduciary understandings that underlie the Constitution's meaning, rather than on some abstract moral or political theory.

All of which brings us back to the facts of Bolling v. Sharpe. We cannot see any good reason why schools in the District of Columbia should have been segregated by race. Access to government facilities is precisely the sort of thing that seems to call for a presumption of equal access by all beneficiaries. Race does not rebut that presumption when the disadvantaged people are among the principals to whom agencies owe duties of impartiality. If Congress is bound by fiduciary duties when legislating for the District of Columbia, and if constitutional meaning should drive constitutional decision making, Bolling is quite an easy case to decide.

Were Congress acting pursuant to the Necessary and Proper Clause, we would have no trouble saying that that clause incorporates the background rules of fiduciary duty and forbids discrimination based on race. But Congress in Bolling did not act pursuant to the Necessary and Proper Clause. It acted pursuant to the Enclave Clause, which authorizes Congress "[t]o exercise exclusive Legislation in all Cases whatsoever, over such District (not exceeding ten Miles square) as may, by Cession of particular States, and the Acceptance of Congress, become the Seat of the Government of the United States . . . "129 Do fiduciary duties apply to Congress 
only through the Necessary and Proper Clause, or do they apply as background principles through the law of agency?

In previous work, one of us has said the former, ${ }^{130}$ but he now thinks that is mistaken, for the reasons that we have already given. The Necessary and Proper Clause confirms and clarifies the agency-law character of the Constitution as it applies to Congress, but it does not create or exhaust that character. Members of Congress are agents, just as are executive and judicial officials. They are fiduciaries, just as are executive and judicial officials. That is true whether they are legislating under the Necessary and Proper Clause, the District Clause, or the Weights and Measures Clause.131 This conclusion is strengthened by ratification-era representations from the Constitution's advocates that the Necessary and Proper

130 See Gary Lawson, Delegation and Original Meaning, 88 VA. L. REv. 327, 391-94 (2002).

131 Because one of the chief fiduciary responsibilities of an agent is to exercise the duties of the agency personally, see Natelson, supra note 11, at 58-59, the fiduciary character of the Constitution, rather than the Necessary and Proper Clause as Professor Lawson has previously said, see Lawson, supra note 129, at 392-93, establishes a nondelegation principle. Does that mean that the President must personally serve warrants and make arrests? Of course not, because the "executive Power" is a power either to exercise or to supervise execution-to "take Care that the Laws be faithfully executed," not necessarily to execute them personally. It does mean, however, that judges who delegate the effective case-deciding power to law clerks are behaving unconstitutionally and are therefore subject to impeachment and removal.

Accordingly, the nondelegation doctrine applies to exercises of Congress's power under the District Clause and the Territories Clause. Territorial legislatures may therefore be unconstitutional, absent some way to read a permission to delegate into the District and Territories Clauses. This was Professor Lawson's original view when considering the matter, see Gary Lawson, Territorial Governments and the Limits of Formalism, 78 CAL. L. REV. 853, 900-905 (1990), which he changed when he thought that only the Necessary and Proper Clause imported the nondelegation principle into the portions of the Constitution that empower Congress. He would appear to have been right the first time. Also, it means that there is no free pass for Congress when it comes to managing federal lands or other property, again contrary to Professor Lawson's earlier position. See Lawson, supra note 129 , at $392-94$. 
Clause was a mere recital of rules that would have been implicit in the Constitution in any event. ${ }^{132}$

If Congress wants to treat people in the District of Columbia differentially, it is not categorically forbidden from so doing, any more than holders of unlimited powers of appointment are forbidden categorically from giving different amounts to beneficiaries. But Congress, like other kinds of trustees, needs reasonable cause for that action, and in the case of Bolling, reasonable cause was nowhere to be found.

132 See Natelson, supra note 72 , at 100-01. 